\title{
EFFECT OF UNSTABLE RATE OF EXCHANGE ON PERFORMANCE OF QUOTED MANUFACTURING COMPANIES IN NIGERIA
}

\author{
ADEKOLA, OMOTAYO AJIBIKE \\ Department of Accountancy, \\ The Polytechnic, Ibadan. \\ OLAYINKA, SEGUN WALE \\ Department of Accountancy, \\ The Polytechnic, Ibadan. \\ https://doi.org/10.37602/IJSSMR.2021.4402
}

\begin{abstract}
The study examined the Impact of Fluctuating Exchange Rate on Manufacturing Performance in Nigeria. Various literature relevant to the study were examined in other to gain insights into the present situation of the study. The study, therefore, consolidated the gap in the literature to form the basis of research. Relevant data were gathered from the Central Bank of Nigeria Statistical Bulletin for the periods of 2010-2016 and analysed to determine how exchange rate fluctuation affects manufacturing performance. A dummy variable was used to explain the appreciation and depreciation of exchange rate over the periods of research and from the empirical result, it can be inferred that there is a considerable relationship between exchange rate and manufacturing performance. On the basis of the result of findings, it can be concluded that an effective exchange rate has a statistical significance on manufacturing performance in Nigeria.
\end{abstract}

Keywords: Exchange rate, Performance, Manufacturing companies

\subsection{INTRODUCTION}

In recent times, the concept of exchange rate fluctuation has become an increasingly famous topic in developing nations, Nigeria not an exception. This may be because of the clear observance and awareness of the role it plays in an economy. Without a doubt, every country's aim is to achieve a stable rate of exchange with its trading partners. This target becomes enormous and most times too much a dare when the country allows for too much gap between its import and export. This constant challenge of fluctuation in the exchange rate has had its toll on manufacturing companies in Nigeria. As stated by Enekwe, Ordu and Nwoha (2013) the aim of any nation is to experience stability in its foreign exchange rate but this goal has not been achieved in Nigeria despite the introduction of devaluation to stimulate export and bring stability into the rate of exchange in the country.

As stated by Bakare (2011) and cited by Akinmulegun and Falana (2018) exchange rate reforms which ought to give way for macroeconomic stability, recovery and sustainable development in the Nigerian economy have continued to be a disadvantage in terms of macroeconomic performances. The different regimes have been accompanied by instability and uncertainties. The non-actualisation of this ambition has negatively made manufacturing 


\title{
International Journal of Social Sciences and Management Review
}

\author{
Volume: 04, Issue: 04 "July - August 2021"
}

ISSN 2582-0176

companies in Nigeria to be an object of dwindling exchange rate and posed a serious threat to their going concern status to the extent of not being able to realise enough earnings to distribute to their shareholders regularly and contribute immensely to the GDP. In fact, studies proved that the Nigerian manufacturing sectors' contribution to GDP has not been stable in recent years compared to some other developing countries. GDP from manufacturing companies in Nigeria decreased to \#1,608,461.83 in the first quarter of 2019 from \#1,686,416.37 in the fourth quarter of 2018. GDP from manufacturing in Nigeria averaged \#1,413,401.85 from 2010 until 2019, reaching an all time high of \#1,718,985.30 in the third quarter of 2014 and in 2012, it stood at $4.16 \%$, falling short of the required rate for development (tradingeconomic.com/National Bureau of Statistics, Nigeria, 2019). These aforementioned problems can also be said to have stemmed from the 1980s when it was observed that manufacturing firms in Nigeria experienced relative stagnation as the sectors value-added per capital lagged behind that of many comparative countries.

The controversy and sensitivity of Exchange rate policies in developing economies as a result of the brand of structural transformations needed, such as reducing imports or expanding nonoil exports, have always led to the deterioration of the nominal exchange rate. Dada and Oyeranti (2012) as cited by Enekwe, Ordu and Nwoha (2013) exclaimed that the distortions embedded in the overvalued exchange rate regime had become a debatable issue in developing countries especially those economies (like Nigeria) that rely to a large extent on imports for their production and consumption. This is so because over the years it has been observed that manufacturing companies in Nigeria have outrageously grown to be dependent on imported materials for the production of goods. This is partly because of the unstable government policies adopted from time to time. A policy like selective credit control (which means giving certain preference of loan obtainable to a particular sector as may be desired by the government) is directed towards the agricultural sector could help in increasing the availability of raw material that could be used for production in the manufacturing sector. For example, if the government policies favour the agriculture sector, raw materials like cocoa will be available in large quantities for the production of beverages.

Also, government tends to manoeuvre the exchange rate policy from time to time. This also determines how dependent the manufacturing companies are on imported material. At a point, flexible exchange rate policy (which is a rate that is determined by the forces of demand and supply) is adopted and before its impact could be felt, the fixed exchange rate policy (which means fixing an exchange rate by the government) is immediately introduced. These rapid adoptions of different exchange rate policies lead to frequent fluctuation in the sector. According to Williams (2018), the situation of things at present where the world has become a global village and financial markets are integrated on an online platform, called for countries to employ concrete strategies that can help to absorb risk involved in exchange rate fluctuation since no nation is immune against the ugly consequences of exchange rate fluctuations.

However, despite several measures put in place so far and due to the unrealisation of the goal of SAP, manufacturing companies in Nigeria continue to consistently battle with the frequent fluctuating exchange rates. Bakare (2011) as cited by Akinmulegun and Falana (2018) exclaimed that several reforms of exchange rate ought to put the Nigerian economy on the path of macroeconomic stability, recovery and sustainable development, but rather, the 


\title{
International Journal of Social Sciences and Management Review
}

\author{
Volume: 04, Issue: 04 "July - August 2021"
}

ISSN 2582-0176

country has continued to be at disadvantage in terms of macroeconomic performances. Hence, this study seeks to examine the effect of exchange rate fluctuation on the performance of manufacturing companies in Nigeria.

\subsection{LITERATURE REVIEW}

\subsection{Empirical Studies}

The inquisitiveness to proffer lasting panacea to the ever-skyrocketing mediocrity in firms' corporate performance has given spur to increasing the debate among scholars on the impact of fluctuating exchange rate on the performance of manufacturing companies in Nigeria. The result of most of the researchers carried out is either positive or negative.

Williams (2018) investigated the impact of exchange rate fluctuations on a firm's performance in Nigeria through the formulation of seven hypotheses. The study made use of panel data covering the periods of 2012 to 2016. The results of the ordinary least square method employed revealed that the exchange rate plays a significant impact on Return on Investment as most of the banks are involved in exchange rate transactions. Also, the regression result shows that there is a positive relationship between Return on Investment and exchange rate of 145.4265 . This implies that a unit increases in the exchange rate of 145.4265 will bring about a rise of 145.4265 in Return on Investment. In a similar study, Akinmulegun and Falana (2018) examined the effects of exchange rate fluctuation on the Industrial Output Growth in Nigeria using time series data sparring from the period 1986 to 2015. Johansen's Co-Integration model was employed to explore the long-run relationship among the variables used, while the Vector Error Correction Model (VECM) was used to evaluate the short and long-run dynamic among the variables and the Granger Causality used to measure contemporaneous relationship among the endogenous variables. The dynamic correlation of the variables was captured by the analyses of impulse response and variance decomposition. The results of the analysis indicate a unidirectional causality from Exchange rate to Industrial output. The response of industrial output to the shock from the exchange rate was positive and significant; more specifically in the initial years, while the response to shock from other variables was little in magnitude and not as significant as the exchange rate.

More so, Dhasmana (2015) explored the impact of real exchange rate changes on the performance of Indian manufacturing firms over the period 2000- 2012, using Panel-VAR. The empirical analysis showed that real exchange rate movements have a significant impact on Indian firms' performance but the impact varied across the different firm and industry characteristics. Results from Panel-VAR also proved that appreciation and depreciation affect firms' performance differently. In the work of Enekwe, Ordu \& Nwoha (2013) where four (4) variables such as manufacturing gross domestic product (MGDP), manufacturing foreign private investment (MFPI), manufacturing employment rate (MER) and Exchange rate (ER) were employed, it was discovered that manufacturing foreign private investment (MFPI) and Exchange rate (ER) have a positive effect on manufacturing gross domestic product (MGDP). Based on the above findings, the researcher recommends that government should stimulate export diversification in the area of agriculture; agro-investment, and agro-allied industries, oil allied industries such will improve Exchange rate fluctuations in the manufacturing sector in Nigeria Economy. 


\title{
International Journal of Social Sciences and Management Review
}

\author{
Volume: 04, Issue: 04 "July - August 2021"
}

ISSN 2582-0176

Musa and Sanusi (2013) made use of a Vector Error Correction (VEC) model to determine the influence of changes in relative prices and exchange rate on the aggregate industrial output of Nigerian firms between 1970 to 2011. The results of their study revealed that changes in exchange rate coupled with inflation will always have a great influence on the industrial output of firms in Nigeria. Contrary to this, the result of Eme and Johnson (2012) in their study where they examined the effect of exchange rate movements on real output growth in Nigeria for the periods 1986 - 2010 revealed that Nigeria economic growth is only being directly influenced by monetary variables and that there is no evidence of a strong direct relationship between changes in the exchange rate and output growth. In the same vein, Opaluwa, Umeh and Abu (2010) discovered that exchange rate has an adverse significant effect on Nigerian manufacturing outputs. In the study, a linear regression tool was used to investigate the effect of exchange rate fluctuations on the Nigerian manufacturing sector during the periods of twenty (20) years (1986 - 2005).

Also, Owolabi \& Adegbite (2012) examined the effects of foreign exchange regimes on industrial growth in Nigeria for the period of 21 years $(1985-2005)$. This study found out that the exchange rate has significant effects on economic growth with an adjusted R2 of 69\%. In the same vein, Ehinomen \& Olodipo (2012) exclaimed that in Nigeria, exchange rate appreciation has a significant relationship with domestic output and it will promote growth in the manufacturing sector. It also ascertained that there is a positive relationship between the manufacturing gross domestic product and inflation. However, the study of Dada \& Oyeranti (2012) gave a contrary result as the authors discovered no evidence of a strong direct relationship between changes in the exchange rate and GDP growth. The study only indicated that fiscal and monetary policies and other economic variables particularly the growth of exports (Oil) affected economic growth in Nigeria. Bakare (2011) in a similar work where empirical analysis was carried out on the effect of foreign exchange rate reforms on the performances of private domestic investment in Nigeria using the ordinary least square multiple regression analytical method, it was revealed that there exists a negative but significant relationship between floating foreign exchange rate and private domestic investment in Nigeria.

\subsection{Gap in Literature}

Carefully observing the available literature reviewed, it was discovered that the researchers have divergent views on the impact of exchange rate fluctuation on the performance of manufacturing companies in Nigeria. Also, the major research works focused on the general effect of exchange rate on manufacturing companies whereas little or no attention was given to specific areas like performance or profitability of the companies, thereby leading to this research work.

In view of this, this study aims at closing this gap by examining the impact of exchange rate fluctuation on the performance of manufacturing companies in Nigeria.

\subsection{Theoretical Framework}

\subsection{Frictional Theory of Profits}




\section{International Journal of Social Sciences and Management Review}

According to this theory, there exists a normal rate of profit which is a return on capital that must be paid to the owners of capital as a reward for saving and investment of their funds rather than to consume all their income or hoard them.

In a static economy where no unanticipated changes in demand or cost conditions occur, in long-run equilibrium the firms would be earning only a normal rate of profit on their capital and entrepreneurial talents. Under these conditions, economic profits would not accrue to the firms.

Frictional theory of profit explains that shocks or disturbances occasionally occur in an economy as a result of unanticipated changes in product demand or cost conditions which cause disequilibrium conditions. It is these disequilibrium conditions that brings into existence positive or negative economic profits for some firms.

Thus, according to frictional theory, economic profits exist for some time because of frictional factors which prevent an instantaneous adjustment of the system to the new conditions. When economic profits are made in the short run, more firms will enter the industry in the long run until all economic profits are driven down to zero (that is, firms will be making only normal returns or profits on their capital investment).

On the other hand, when firms are making losses (i.e. negative profits), some firms will leave the industry. This will cause the price of the product to rise so that losses are eliminated and the remaining firms make only normal profits.

The theory focuses on the economic and normal profit of a firm which could be either negative or positive based on the circumstances. Negativity or positivity of profit is caused by changes in demand without proportionate changes in supply or vice-versa. This leads to fluctuation in the exchange rate (i.e. at the long run).

\subsection{METHODOLOGY}

The purpose of this study is to investigate the impact of exchange rate fluctuation on the performance of manufacturing companies in Nigeria. Secondary data sourced from Central Bank of Nigeria Bulletins, Central Bank of Nigeria Annual Reports and other developmental indicators were gathered to achieve this objective.

This study employed a quantitative method of data using Analysis of Variance (ANOVA) and regression analysis with the aid of the Statistical Package for Social Science (SPSS).

\subsection{Model Specification}

To achieve the objective of this study, the two variables involved are exchange rate as an independent variable and performance as the dependent variable. The independent variable is proxied by Exchange Rate (ER), Inflation Rate(IR), Interest Rate(INTR) and Dummy Variable(DV) (which is the percentage change in the exchange rate) while the dependent variable is proxied by manufacturing gross domestic product(MGDP).

The empirical model is as follows: 


\section{International Journal of Social Sciences and Management Review}

$\operatorname{MGDP}=\beta \_(0)+\beta 1 \mathrm{ER}+\beta 2 \mathrm{IR}+\beta 3 \mathrm{INTR}+\beta 4 \mathrm{DV}+\mu \mathrm{i}$

Apriori Expectation:

$\beta \_1, \ldots \ldots . \beta \_$4greater than zero

Where;

$\beta \_(0)$ is the constant term, $\llbracket \beta \rrbracket \_1, \ldots \ldots \beta_{-} 4$ are the slopes of the regression to be estimated and $\mu \mathrm{i}$ is the stochastic error term.

Degree of Significance: The level of significance used for this study is $5 \%$

\subsection{DATA ANALYSIS AND FINDINGS}

Table no. 1 showed the results of descriptive analysis of the data collected on five variables Manufacturing Gross Domestic Product (MGDP), Exchange Rate (ER), Inflation rate (IR), Interest Rate (INTR) and Dummy Variable (DV) from 2010-2016. It provided information about sample static mean and standard deviation. The table reveals the description of the variables according to their average and deviation which measured the extent to which the data series dispersed around the mean.

\begin{tabular}{|l|l|l|l|}
\hline \multicolumn{1}{|l|}{ TABLE 1: DESCRIPTIVE STATISTICS } \\
\hline & Mean & Std. Deviation & N \\
\hline MGDP (BILLION) & 5935.8933 & 2565.63858 & 9 \\
\hline EXC RATE & 177.8256 & 50.63902 & 9 \\
\hline INF RATE & 11.3333 & 2.54264 & 9 \\
\hline INT RATE & 10.6667 & 2.83119 & 9 \\
\hline DUM RATE & 10.0578 & 17.40055 & 9 \\
\hline
\end{tabular}

Test of Significance for Individual Regression Co-efficient

The T-test was employed in other to test for the significance of individual regression coefficient of the adopted model.

Table 2 below revealed that the coefficient $\beta 0, \beta 2, \beta 3, \beta 4$, are insignificant to the model while $\beta 1$ is significant to the fitted model.

This shows that, out of the variables, only the explanatory variable (Exchange rate) contributed meaningfully to the fitted model. 


\section{International Journal of Social Sciences and Management Review}

Volume: 04, Issue: 04 "July - August 2021"

ISSN 2582-0176

By implication, if the exchange rate increases by 1 unit MGDP will increase by 99.073 . On the other hand, if the interest rate and inflation rate increase by 1 unit, MGDP will fall by 667.217 and 43.708 respectively.

Table 2: Summary of t-test for individual $\beta$

\begin{tabular}{|l|l|l|l|l|l|l|l|l|}
\hline $\begin{array}{l}\text { ESTIM } \\
\text { ATES }\end{array}$ & $\begin{array}{l}\text { VALUES } \\
(\mathrm{B})\end{array}$ & $\begin{array}{l}\text { STANDAR } \\
\text { D ERROR }\end{array}$ & t-cal & $\mathrm{t}$ tab & SIG. & $\begin{array}{l}\text { Decision } \\
\text { base on } \mathrm{H}_{0}\end{array}$ & $\begin{array}{l}\text { Decision } \\
\text { base on } \mathrm{H}_{1}\end{array}$ & CONCLUSION \\
\hline$\beta_{0}$ & -2187.026 & 4314.190 & -.507 & 1.895 & .639 & Accept & & Insignificant \\
\hline$\beta_{1}$ & 99.073 & 26.943 & 3.677 & 1.895 & .021 & & Accept & Significant \\
\hline$\beta_{2}$ & -667.217 & 157.239 & -4.243 & 1.895 & .013 & Accept & & Insignificant \\
\hline$\beta_{3}$ & -43.708 & 153.118 & -.285 & 1.895 & .789 & Accept & & Insignificant \\
\hline$\beta_{4}$ & -145.835 & 75.330 & -.989 & 1.895 & .125 & Accept & & Insignificant \\
\hline
\end{tabular}

\subsection{TESTS FOR OVERALL SIGNIFICANCE OF THE REGRESSION}

Here, F-Test is used to test for overall significance of regression.

Hypothesis:-

H0: $\quad \beta 0=\beta 1=0$ (Not Significant to the model)

H1: $\quad \beta 0 \neq \beta 1 \neq 0$ (Significant to the model)

The ANOVA table below coupled with the calculation in the appendix revealed that the joint test of the variables does contribute meaningfully to the fitted model. This simply means that combination of the explanatory variable is significant to test for "The Impact of Fluctuating Exchange Rate on Manufacturing Performance".

TABLE 3: ANALYSIS OF VARIANCE (ANOVAa)

\begin{tabular}{|l|l|l|l|l|l|l|}
\hline \multicolumn{2}{|l|}{ Model } & Sum of Squares & df & Mean Square & F & Sig. \\
\hline \multirow{2}{*}{1} & Regression & 50276013.476 & 4 & 12569003.369 & 21.08 & .006 b \\
& Residual & 2383997.179 & 4 & 595999.295 & & \\
& Total & 52660010.655 & 8 & & & \\
& & & & & & \\
\hline
\end{tabular}

a. Dependent Variable: MGDP (BILLION)

b. Predictors: (Constant), DUM RATE, INF RATE, INT RATE, EXC RATE 


\section{International Journal of Social Sciences and Management Review}

Volume: 04, Issue: 04 "July - August 2021"

ISSN 2582-0176

\subsection{Estimation of Correlations between the Variables}

The Pearson correlation between Manufacturing Gross Domestic Product (MGDP) and Exchange rate (MGDP) has shown in table 4 below gives 0.683 . This reveals that there is the moderate positive degree of relationship between the Manufacturing Gross Domestic Product (MGDP) and Exchange rate (ER).

The Pearson correlation between Manufacturing Gross Domestic Product (MGDP) and Inflation rate (IR) gives -0.310 . This reveals that there is the negative degree of relationship between the Manufacturing Gross Domestic Product (MGDP) and Inflation rate (IR).

The Pearson correlation between Manufacturing Gross Domestic Product (MGDP) and Interest rate (INTR) gives 0.739 . This reveals that there is the moderate positive degree of relationship between the Manufacturing Gross Domestic Product (MGDP) and Interest rate (INTR).

The Pearson correlation between Manufacturing Gross Domestic Product (MGDP) and Dummy rate (DR) gives 0.557 . This reveals that there is the moderate positive degree of relationship between the Manufacturing Gross Domestic Product (MGDP) and Dummy rate (DR).

Table 4: Correlation Coefficient

\begin{tabular}{|l|l|l|l|l|l|}
\hline \multicolumn{2}{|c|}{} & $\begin{array}{l}\text { MGDP } \\
\text { (BILLION) }\end{array}$ & $\begin{array}{l}\text { EXC } \\
\text { RATE }\end{array}$ & $\begin{array}{l}\text { INF } \\
\text { RATE }\end{array}$ & $\begin{array}{l}\text { INT } \\
\text { RATE }\end{array}$ \\
\hline $\begin{array}{l}\text { Pearson } \\
\text { Correlation }\end{array}$ & $\begin{array}{l}\text { MGDP } \\
\text { (BILLION) }\end{array}$ & 1.000 & .683 & -.310 & .739 \\
\cline { 2 - 6 } & EXC RATE & .683 & 1.000 & .429 & .558 \\
\cline { 2 - 6 } & INF RATE & -.310 & .429 & 1.000 & -.234 \\
\cline { 2 - 7 } & INT RATE & .739 & .558 & -.234 & 1.000 \\
\cline { 2 - 7 } & DUM RATE & .557 & .972 & .504 & .465 \\
\hline \multirow{5}{*}{ Sig. (1-tailed) } & $\begin{array}{l}\text { MGDP } \\
\text { (BILLION) }\end{array}$ &. & .021 & .209 & .011 \\
\cline { 2 - 7 } & EXC RATE & .021 &. & .125 & .059 \\
\cline { 2 - 7 } & INT RATE & .209 & .125 &. & .272 \\
\cline { 2 - 7 } & INF RATE & .011 & .059 & .272 &. \\
\cline { 2 - 7 } & DUM RATE & .060 & .000 & .083 & .104 \\
\hline \multirow{5}{*}{$\mathrm{N}$} & $\begin{array}{l}\text { MGDP } \\
\text { (BILLION) }\end{array}$ & 9 & 9 & 9 & 9 \\
\cline { 2 - 7 } & EXC RATE & 9 & 9 & 9 & 9 \\
\cline { 2 - 7 } & INT RATE & 9 & 9 & 9 & 9 \\
\cline { 2 - 7 } & INF RATE & 9 & 9 & 9 & 9 \\
\cline { 2 - 6 } & DUM RATE & 9 & 9 & 9 & 9 \\
\hline
\end{tabular}

$\begin{array}{lll}r_{\mathbf{y x} 1} & = & 0.683 \\ r_{\mathbf{y x} 2} & = & -\mathbf{0 . 3 1 0}\end{array}$




\section{International Journal of Social Sciences and Management Review}

$r_{\mathbf{y x 3}}=0.739$
$r_{\mathbf{y x} 4}=0.557$

The findings of this study are consistent with the results of Ehinomen \& Olodipo (2012), Williams (2018), Akinmulegun and Falana (2018), Musa and Sanusi (2013), Enekwe, Ordu \& Nwoha (2013), Enekwe, Ordu \& Nwoha (2013) where the positive significant relationship was found between exchange rate and performance of manufacturing companies in Nigeria. However, the results of Eme and Johnson (2012), Dada and Oyeranti (2012), Opaluwa, Umeh and Abu (2010) are contrary to the findings of this study.

\subsection{CONCLUSION AND RECOMMENDATION}

From the series of exposition and empirical analyses conducted in this study, it was discovered that there is a considerable relationship between exchange rate and manufacturing performance. On the basis of the result of findings, it can be concluded that an effective exchange rate has a statistical significance on manufacturing performance in Nigeria.

It is therefore recommended that the government should direct concerted efforts towards the stabilization of the exchange rate of the country by introducing policies that will deal with both the demand and supply sides of foreign exchange instead of expending extraneous time in dealing with another variable such as the interest rate for loan obtainable in the manufacturing sector.

\section{REFERENCE}

Akinmulegun, \& Falana (2018). Exchange Rate Fluctuation and Industrial Output Growth in Nigeria. International Journal of Economics and Financial Research, 4(5), 145-158.

Bakare, A. S. (2011). The consequences of foreign exchange rate reforms on the performances of private domestic investment in Nigeria. International Journal of Economics and Management Sciences, 1(1): 25-31.

Dada, E.A \& Oyeranti, O.A (2012). Exchange rate and macroeconomic aggregates in Nigeria. Journal of Economics and Sustainable development. 3(2), 93 - 101.

Dhasmana, A. (2015). Transmission of real exchange rate changes to the manufacturing sector: The role of financial access. International Economics, 143(2015): 48-69.

Ehinomen, C. \& Oladipo, T.I. (2012). Exchange rate management and the manufacturing sector performance in the Nigerian Economy. IOSR Journal of Humanities and Social Science 5(5): $1-12$.

Eme, O. A. \& Johnson, A. A. (2012). Effect of exchange rate movements on economic growth in Nigeria. CBN Journal of Applied Statistics, 2(2): 1-28.

Enekwe, C. I., Ordu, M. M. \& Nwoha, C. (2013). Effect of Exchange Rate Fluctuations on Manufacturing Sector in Nigeria. European Journal of Business and Management 5(22), 67-73 


\section{International Journal of Social Sciences and Management Review}

Musa, Y. \& Sanusi, J. A. (2013). Industrial output response to inflation and exchange rate in Nigeria: An empirical analysis. Journal of Economics and Sustainable Development, 4(20): 74-81.

National Bureau of Statistics (2019). Nigeria GDP from Manufacturing.

Opaluwa, D., Umeh, J. C. \& Abu, A. A. (2010). The effect of exchange rate fluctuations on the Nigerian manufacturing sector. African Journal of Business Management, 4(14): 2994-98.

Owolabi, A.U. \& Adegbite, T.A. (2012). The effect of foreign exchange regimes on industrial growth in Nigeria. Global Advanced Research Journal of Economic, Accounting and Finance 1(1): $1-8$.

Williams, H.T. (2018). An Empirical Investigation Of The Impact Of Exchange Rate fluctuations On The Performance Of Selected Listed Firms In Nigeria. Journal of Business Management and Economic Research, 2(3), 1-10 